\title{
The Polyhedral Victim and the Patchwork Abuser: A Comparative Study of Names and Naming in Vladimir Nabokov's Lolita (1955) and Maria Velho da \\ Costa's Myra (2008).
}

\section{TOM STENNETT}

As Myra, the eponymous heroine of Maria Velho da Costa's 2008 novel, dresses for her master/lover Orlando Gabriel on the night of her sixteenth birthday, she likens herself to 'uma Lolita velha' (an old Lolita) and 'uma ninfa de mariposa desabrochada da pupa. Ridícula, com uma previsão de sobrevida de um dia, ou dois' (a nymphic butterfly newly emerged from its cocoon. Ridiculous-looking, with a life expectancy of a day, or perhaps two. Myra, p. 150). ${ }^{1}$ It is no coincidence that Myra is Russian, and that she is compared to the preferred creature of the lepidopterist Vladimir Nabokov, the Russian author of the English-language novel Lolita (1955).

Myra is described as an 'old' and 'nymphic' Lolita because she has just turned sixteen — two years older than the fourteen put forward by Humbert Humbert, Lolita's narrator and the titular child's kidnapper and abuser, as the upper age-limit for a nymphet; a hebephilic ${ }^{2}$ fantasy that Humbert sketches in an early part of the novel:

Between the age limits of nine and fourteen there occur maidens who, to certain bewitched travellers, twice or many times older than they, reveal their true nature which is not human, but nymphic (that is demoniac): and these chosen creatures I propose to designate as "nymphets". (Lolita, p. 16)

\footnotetext{
${ }^{1}$ Maria Velho da Costa, Myra (Lisbon: Assírio e Alvim, 2008). All translation of quotations from Myra are my own, and follow the Portuguese in brackets, along with a page number.

${ }^{2}$ Hebephilia is the persistent sexual preference by adults for early adolescent children.

${ }^{3}$ Nabokov, The Annotated Lolita ed. Alfred Appel (Harmondsworth: Penguin, 2000).
} 
Nymphets are sexualized fantasies that exist only in the eyes of the paedophilic beholder; they are demonic doubles of human referents. In the abuser's mind, the nymphic form is 'truer' than her human equivalent.

As Myra looks at her image in the mirror, she refuses to define herself, or let another define her, in terms of anyone else:

Agora talvez ganhasse, no horror da beleza, no horror da beleza do duplo, de ser dupla de outrem, substidupla, riu-se. [...]

E não é assim que se ama, se adora, com a carga de ressuscitar a memória de alguém, outrem?

Não, disse Myra nobremente, diante do espelho, Se não sou preferida, não sou ninguém $[\ldots]$.

(Myra, p. 149)

[Now perhaps she gained, in the horror of beauty, in the horror of a doppel-beauty, of being someone else's double, a substi-duo. She laughed to herself. [...]

Is it not thus that we love, we adore - with the charge of resuscitating the memory of someone, of someone else?

"No," said Myra nobly, in front of the mirror. "If I am not the chosen lover, I am no one $[\ldots] . "$.."

Myra, who has no meaningful contact with any girls of her own age throughout the novel, refuses to identify with the 'outras raparigas' - those young girls, like Lolita, that she reads about in novels or watches on film: 'É estranho, disse Myra, eu não me apaixono como as outras raparigas. Não perco a cabeça' (“It's odd,” said Myra, “I don't fall in love like other girls. I don't lose my head.”, p. 150). Through the voice of her protagonist, Velho da Costa establishes a relationship with Lolita at the same time that she distinguishes her heroine from Nabokov's: when away from the gaze of the predatory adults that stalk the novel's pages, Myra is no double or substitute, nor is she unreal like those girls that she has read about or watched. 
The episode in front of the mirror underlines Myra's ability, honed throughout the novel, to take on new identities. These personae serve to protect her chosen identity, associated with the name 'Myra', that she only shares with her faithful hound, Rambo.

In this article, I examine the significance(s) of names and the act of naming in Myra and Lolita. First, I consider the implications of the 'extratextuality' of these novels' eponymous protagonists, given that the method of intertextual decoding, encouraged elsewhere in both novels, is thwarted if the reader attempts to look for literary/cultural predecessors for Lolita or Myra. Second, I argue that identities serve as sham (Lolita) and fragile (Myra) protection respectively in the novels. Myra's adoption of personae entails a deflection of the unblinking look that is cast upon her by the dangerous adults that she meets on her tour of Portugal. In Lolita, the novel's fictional editor uses false identities (putatively) to conceal the identity of the abused child from his readership. The crucial difference is that Myra names herself as a part of a survival strategy; Lolita is named by her abusers, who commandeer her story and her literary representation. Myra has an agency that is denied Lolita. Last, I situate Nabokov's decision to write a narrative from the perspective of a male abuser, and Velho da Costa's determination to centre her novel around a female victim, in the specific contexts in which these texts were conceived.

\section{Lolita and Myra: Extratextual Protagonists}

Whereas the novels Myra and Lolita are replete with intertextual references (Myra and Humbert both being very well-read), the names 'Myra' and 'Lolita' do not point to clear predecessors. Lolita's intertextuality is controlled by her abuser, Humbert 
Humbert, and by the author, Nabokov. Myra, an outsider in Portugal, negotiates the dangerous world of Velho da Costa's novel through the invention of false identities. In Myra, make-believe is a survival strategy; in Lolita, control of the narration of the eponymous protagonist's story is ensured by Humbert Humbert through the construction and control of her identity. Whereas Myra adeptly inserts herself in a transcultural textuality, Lolita is inserted in an intertextual genealogy of her writers' creation.

Lolita's main body is a text written by Humbert Humbert while in prison. His account is framed by a foreword written by John Ray Jr., the fictional editor. As is the case with 'Lolita', Humbert Humbert is not the fictional author's real name; the moniker is an identity chosen to safeguard the writer's identity from the reading public.

Humbert's text is the account of his 'love' for Lolita, whom he meets when he accepts a teaching position at a school in the fictional New England town of Ramsdale. In the novel, Lolita is also referred to as 'Dolores Haze' — an approximation of her real name chosen by John Ray. Humbert soon becomes sexually obsessed with the then twelve-year-old Dolores, whose mother Humbert marries. Humbert murders the mother and kidnaps Dolores, whom he sexually abuses for several years while they travel across North America, stopping for a time in the fictional town of Beardsley. During a second road trip, Humbert is followed by the playwright Clare Quilty, whom Humbert had met in the hotel where he first raped Dolores. While in Texas, Dolores, having fallen ill, disappears from the hospital where she was being treated. Several years later, when Dolores has reached the age of seventeen, Humbert receives a letter 
from her telling him that she is now living in Coalmont, Tennessee; that she is married to a Richard Schiller, pregnant and in dire financial difficulty. Humbert tracks down Dolores, who tells him that she was not abducted: she left of her own volition with Quilty, from whom she later escaped. Humbert tracks down Quilty and murders him. The novel ends with Humbert's arrest. Lolita's fate is absent from the final chapters. A rereading of Ray's foreword reveals that a 'Mrs. "Richard F. Schiller"' had died in childbirth, prompting the publication of Humbert's text (Lolita, p. 4), for the fictional author had stipulated that his novel should only be published after Lolita's death (pp. 308-309).

The intertextual genealogy of Lolita (novel and protagonist) is constructed and controlled by Humbert and by Nabokov. Humbert states that Lolita's only precursor is another inhabitant of the novel's literary universe: 'Did she have a precursor? She did, indeed she did' (p. 9) — Annabel, a childhood love of Humbert's'. ${ }^{4}$ In a 1964 interview with Playboy, Nabokov explains his choices for the various names given to Lolita, and her abuser's unusual moniker. The author places an emphasis on the importance of the 'lyrical lilt' of the nymphet's name:

One of the most limpid and luminous letters is "L." The suffix "-ita" has a lot of Latin tenderness, and this I required too. Hence: Lolita. However, it should not be pronounced as you and most Americans pronounce it: Low-lee-ta, with a heavy, clammy "L" and a long "o." No, the first syllable should be as in "lollipop," the "L" liquid and delicate, the "lee" not too sharp. ${ }^{5}$

In contrast, Humbert Humbert's name was chosen for its sinister suggestiveness:

\footnotetext{
${ }^{4}$ One possible literary precursor for Lolita has been identified by James T. Bratcher - a character from Mayne Reid's The War Trail (1857) — but neither Humbert nor Nabokov direct the reader towards Reid's novel. James T Bratcher, 'Lolita: A Probable Source of Nabokov's Name for his Temptress', Notes and Queries, 56 (3) (2009), 427.

${ }^{5}$ Alvin Toffler, 'Interview: Vladimir Nabokov', Playboy, January 1964,

$<$ http://reprints.longform.org/playboy-interview-vladimir-nabokov>, [accessed 14 October 2016].
} 
The double rumble is, I think, very nasty, very suggestive. It is a hateful name for a hateful person. It is also a kingly name, and I did need a royal vibration for Humbert the Fierce and Humbert the Humble. ${ }^{6}$

If 'Lolita', pronounced correctly, afforded Nabokov's ears pleasure, his narrator, at the beginning of the novel, describes the sensuous enjoyment that he experiences when pronouncing the three syllables that constitute the name that he has given to his nymphet: 'Lo-lee-ta: the tip of the tongue taking a trip of three steps down the palate to tap, at three, on the teeth. Lo. Lee. Ta' (p. 9). The function of Lolita's name is lyrical — in the sense of poetic phonetics, and of lyric poetry: 'Another consideration was the welcome murmur of its source name, the fountain name: those roses and tears in "Dolores." My little girl's heart-rending fate had to be taken into account together with the cuteness and limpidity'. ${ }^{7}$

The novel Lolita has its own precursor, a novella written in 1939, but discarded by Nabokov, called Волшебник (translated by his son Dimitri as The Enchanter) and signed by 'V. Sirin', a pseudonym in Nabokov's Russian works. The anonymous pubescent girl in the novella is a spectral presence, spending most of the narrative away from the (also unnamed) male abuser. Unlike Lolita, who, according to Humbert, invites her abusers' advances, the girl in The Enchanter screams in fear and tries to escape when her step-father attempts to rape her in a hotel room as she sleeps. Dimitri Nabokov writes in his postface, 'On a Book Entitled The Enchanter', regarding the relationship between Волшебник and Lolita: 'Dolores Haze may, as [Vladimir] Nabokov says, be "very much the same lass" as the Enchanter's victim,

\footnotetext{
${ }^{6} \mathrm{Ibid}$.

${ }^{7}$ Ibid.
} 
but only in an inspirational, conceptual sense'. ${ }^{8}$ Lolita's place in Nabokov's textual universe is strictly controlled by the author, his son and the fictional narrator.

Myra is a Russian child immigrant who begins the novel as a stranger to and within Portuguese culture. As she reads books and watches films, Myra inserts herself in a transcultural textuality, constructing her identities in and through cultures, inventing 'contos' (short stories) to fool potential predators, whilst preserving her chosen identity, Myra.

Myra tours Portugal with a former fighting dog, Rambo/Rimbaud, having escaped from her family, who live with other Eastern European immigrants in a warehouse in the coastal town of Caparica, south of Lisbon. Thereafter, Myra traverses a world filled with predatory adults, including the lecherous German Kleber and his lover, the austere artist Mafalda, who hosts Myra in her 'Casa Grande'. 9 Having escaped Mafalda's house, Myra is eventually taken into the household of the Cape-Verdean mestiço Gabriel Rolando/Orlando. Gabriel persuades Myra to move with him to Lisbon, but they are stopped on their way by three men, who shoot Gabriel and kidnap Myra, taking her to a brothel in Porto. The novel ends with Myra's inevitable ('Tem de ser'; (It has to be). Myra, p. 221) suicide, as she jumps out of her new bedroom window clutching her only friend, the dog Rambo/Rimbaud.

Myra's name immediately signals her foreignness, for ' $y$ ', like ' $k$ ' and ' $w$ ', were only re-introduced to the Portuguese alphabet in 2009, under the Portuguese

\footnotetext{
${ }^{8}$ Dimitri Nabokov, 'On a Book Entitled The Enchanter', in Novellas: The Eye, The Enchanter, The Original of Laura (London: Penguin Classics, 2012), p. 213.

9 'Casa Grande' in Portuguese has clear colonial overtones, as the term traditionally refers to the large rural properties ('Big Houses') of slave-owners in the northeast of Brazil.
} 
Language Orthographic Agreement of 1990, having been initially abolished in the Orthographic Agreement of $1945 .{ }^{10}$ Once introduced into the Portuguese alphabet, the usage of these letters was restricted to acronyms, foreign words not rendered into Portuguese, or nouns and adjectives derived from these terms. ${ }^{11}$

On the novel's first page, the narrator frames Myra as an outsider, like the blinis about which the protagonist reminisces. Her initial identity lies outside the cultural-linguistic system that she has entered, having abandoned her remaining family in Caparica, and before that her native Russia: 'Myra lembrou-se da neve em cima dos telhados de ouro e loiça. E os blinis que não tinham nome nesta terra. Ao princípio nada tinha nome' (Myra remembered the snow that covered the gold and china rooftops. And the blinis that have no name in this land. In the beginning, nothing had a name. Myra, p. 9). The narrator recognises that the foreign object, as an intruder in the receiving culture's linguistic framework, is at first anonymous. Myra will have to accept a label if she wants to participate in this dangerous world, as opposed to remaining mute like Maina Mendes, the eponymous protagonist of another Velho da Costa novel. Variously Sonia/Sophia to Mafalda and Kleber; Maria Flor to a Friar and a Nun who feature in chapter nine; Elena, to a blind man whom the protagonist meets in chapter ten; and finally, Ekaterina/Kate to Gabriel Orlando - Myra's identity is never fixed, shifting according to circumstance. For Ana Filipa Prata, the name Myra points to the protagonist's myriad identities. ${ }^{12}$

\footnotetext{
10 The Portuguese Language Orthographic agreements were international treaties designed to standardize spelling in the Portuguese language across continents.

11 'Acordo Ortográfico da Língua Portuguesa. Assinado em Lisboa a 16 de Dezembro de 1990', $<$ http://www.priberam.pt/docs/AcOrtog90.pdf>, p.6 [accessed 2 December 2016].

${ }^{12}$ Ana Filipa Prata, 'Transgression, Transdifference and Abjection in Maria Velho da Costa's Myra and Teresa Vilaverde's Transe', Portuguese Studies, 33:2 (2017), p. 206.
} 


\section{Names as Shields: Identity as Fragile/Sham Protection}

Unlike in Myra, the reader of Lolita never learns the eponym's given name. Lolita is a sexualised, fantastical identity foisted by Humbert upon the young adolescent girl that he kidnaps and abuses. Lolita is not the girl's only mask. The moniker Dolores Haze, which approximates her real name, should serve to protect the child's identity from prying readers, but the fictitious editor John Ray sees no 'practical necessity' to alter the original name radically. The fictional surname Haze rhymes with the girl's real family name and her forename, Dolores, has not been changed because 'her first name is too closely interwound with the inmost fiber of the book' (Lolita, p. 4). Ray glibly provides, 'for the benefit of old-fashioned readers', several details that would allow anyone interested "to follow the destinies of the "real" people beyond the "true" story' (p. 4). Nabokov's fictional editor thus directs the reader, presumed to be a man ('as the reader will perceive for himself', p. 4), towards the information relating to the events of the novel, and thereby tacitly encourages the 'inquisitive' reader to discover more about the case, exposing the people imbricated in the story. In this respect, Ray resembles Humbert, who, at several points in the narrative, attempts to expose the real names of people to whom he has taken a dislike. Ray acknowledges the existence of such moments:

Save for the correction of obvious solecisms and a careful suppression of a few tenacious details that despite "H.H." 's [Humbert Humbert's] own efforts still subsisted in his text as signposts and tombstones (indicative of places or persons that taste would conceal and compassion spare), this remarkable memoir is presented intact. (p. 3)

The editor's carefree attitude towards the privacy of the people involved in the drama leave us wondering whether Ray was entirely scrupulous in his rectification of these moments of aberration; where the factual erupts into the fiction. Of course, the novel is a fiction, and as such Lolita, Mona Dahl (another 'nymphet'), and the rest are not 
in any danger of being exposed - because they do not exist, except as literary constructs. Nevertheless, the similarities between Ray and Humbert underline the fact that the dangers of this fictional world extend beyond the monstrous Humbert. In the novel, the abuse of the vulnerable, embodied by Lolita, is rampant, goes unnoticed, often escapes punishment until it is much too late, and, because of characters like Ray, continues even after the victim has extricated herself from the clutches of a tormentor.

Ray's supposition that a substantial proportion of Lolita's readership will be interested in the 'real' Lolita seems particularly pertinent nowadays, given contemporary questions over the role of the media and the public gaze in causing undue, added distress to victims of sexual or physical abuse, and the issue of whether victims' names ought to be published by the media. ${ }^{13}$ Although the purpose of Ray's words is not to highlight that particular issue, the fact that both Ray and Humbert feel that they can use Lolita's name(s) as they wish demonstrates the power that these characters have over her. Humbert Humbert's double name reflects his doubled power over Lolita: on the one hand, the protagonist Humbert enjoys, for most of the novel, almost absolute control over her - a defenceless girl whose stasis should not be misinterpreted for assent; on the other, the second and later Humbert, the narrator, takes charge of the evocation and the ordering of the story's events, but also of the representation of the novel's heroine, who is denied the agency of telling her version of events.

\footnotetext{
${ }^{13}$ See, for example, Lisa M Jones, David Finkelhor, and Jessica Beckwith, 'Protecting victims' identities in press coverage of child victimization', Journalism: Theory, Practice and Criticism, 11(3) (2010), p. 348.
} 
Myra is a storyteller, but her narratives and identities are mendacious fictions. Myra deflects the various objectifying looks that are cast upon her by the male predators that inhabit the novel's fictional universe through her hasty invention of alter-egos to protect her chosen identity: 'Myra' ${ }^{14}$ However, Myra is not merely an image, nor is she solely subject to the male predatory gaze that Laura Mulvey suggests is present in the Freudian scopophilic look that traditional film induces the male spectator to cast on the female form, which is 'displayed for his enjoyment (connoting male phantasy)'. ${ }^{15}$ For Mulvey, through a second look, 'that of the spectator fascinated with the image of his like set in an illusion of natural space', the objectification of the female form inherent in the first look is extended to "the control and possession of the woman within the diegesis', as the male spectator identifies with the more complete image of himself: the central male protagonist. ${ }^{16}$ Whereas the 'control and possession' of the girl by a male spectator/reader, encouraged obliquely by the author through the devices of the fictional editor and the narrator, applies more readily to Lolita and its framing texts, the interplay of looks in Myra is complex: Myra is both (self-reflexive) spectator and spectated.

The danger of being looked at is encoded in the name 'Myra'. In the novel's penultimate chapter, Maribel, the girl Myra meets having been kidnapped and taken to D. Adalgisa's brothel, performs a song:

Mira-me Miguel

Como estoy de bonitinha

Xaia de burel

\footnotetext{
${ }^{14}$ For a reading of Myra's 'poetics of a resourceful survival strategy structured by a strong intertextual network, discursive and narrative artificial, and cultural subversion', see Ana Filipa Prata, 'Transgression, Transdifference and Abjection in Maria Velho da Costa's Myra and Teresa Vilaverde's Transe', pp. 205-214 (204).

${ }^{15}$ Laura Mulvey, 'Visual Pleasure and Narrative Cinema' in Leo Braudy and Marshall Cohen, Film Theory and Criticism: Introductory Readings (New York; Oxford: Oxford University Press, 2009), p. 717.

${ }^{16}$ Ibid.
} 
Camijinha de estopinha.

[Look at me, Miguel

How pretty I am

A woolen skirt

A little linen shirt.]

(Myra, p. 216)

'Mira(r)', a verb that exists in Portuguese, but which is more commonly used in Mirandese, seems to refer to the unblinking (male) gaze to which Myra is subject throughout the novel, and which the song's constructed female voice invites.

The chapters that recount Myra's sixteenth birthday, which takes place in Gabriel's 'Casa Branca', alternate between Mulvey's first scopophilic look, and its rejection in favour of a three-dimensional and sympathetic, but not idealised, portrayal of Myra. Similarly, the text hesitates between the representation of Gabriel's relationship with Myra as a heterosexual, male domination of the female body on the one hand, and a harmonious love-bond on the other. ${ }^{17}$ Both representations are subverted.

Chapter seventeen is tinged with a distinctive filmic quality, beginning with a general reference to cinema that suggests that what follows will take place behind the lens of a camera: 'Nonóia [t]razia um sorriso maior que a boca dela e uma bandeja de hotel de cinco estrelas, como ela só vira em filmes, ou séries de luxo brasileiras' (Nonóia beamed a smile broader than her mouth should allow and carried a serving tray of the sort that only exist in five-star hotels, and which Nonóia had only ever seen in films, or classy Brazilian TV series. Myra, p. 139). The chapter is punctuated with

\footnotetext{
${ }^{17}$ Gabriel's age is never specified. When the fifteen-year old Myra first encounters him, the anonymous narrator remarks that he could be in his twenties or thirties (Myra, p. 90).
} 
references to specific films, such as several of Pasolini's movies (p. 140), Long Day's Journey into Night (p. 144), and possibly the 1997 film version of Lolita (p. 150). ${ }^{18}$

The narration moves like a lens across Myra, focusing on her clothes and on her fragmented body, with each outfit that Myra dons, and the concomitant rituals of (un)dressing, loaded with symbolic, if ambiguous, meaning. The nuptial nightdress (one of the household staff, Nonóia, calls it a 'Vistide di noiva', p. 140) that Myra receives as a present from Gabriel represents the handing over, in the novel's twisted patriarchal order, from the girl's absent father to her mutilated husband. Myra's first menstruation in the novel's opening chapter coincided with her flight from her family, and her entry into the dangerous underworld that she traverses. Orlando's dress commemorates Myra's sixteenth birthday: the age when a girl becomes a woman in this world, for Myra's mother and grandmother both had their first children aged sixteen (pp. 140-41). The date marks Myra's sexual initiation; Gabriel waits for Myra to reach the age of consent for fear of being accused a paedophile (pp. 106-107).

Myra's second outfit, a swimming costume 'loaned' by her lover/master, is forcibly removed during a sexually explicit scene, after she has been rescued from an unidentified sea creature (p. 143). Following the undressing scene on the boat, Myra's reformulates her tragic mantra, 'Não vou chorar', to the ambiguous: 'Não vou chorar, nem de alegria, pensou Myra, a água do mar faz isso por mim (“I won’t cry, not even of joy," thought Myra. "The seawater will do that for me." Myra, p. 143).

\footnotetext{
${ }^{18}$ It is unclear whether Myra refers to the Lolita in Nabokov's novel, or that of the 1997 film version.
} 
Myra's and Gabriel's love bond attempts to transcend the colonial dynamics of violence and coercion that structure the underworld portrayed in the novel. Their efforts are futile. Having shown Myra his mutilated genitals, Gabriel declares his love: 'O amor, o teu amor, fria donzela. Quero o que já tenho, mas consentido. Sem recalcitrância, sem jogos de poder, ó russinha. Desde que te vi, vi que me convinhas. Em ti deponho toda a minha pena' (Love, your love, frigid maid. I want what I already have, but with your consent. Without reluctance, without power games. Oh, my little Russian! When I first saw you, I knew that you and I were meant to be. In you I lay down all my pain/pen. Myra, p. 168). The italicised text is a reference to the poem by Luís de Camões addressed to a black slave called Bárbara. The verse in question is a bawdy pun playing on the double meaning of 'pena' in Portuguese, which can refer to 'pain' or 'shame', as well as the poet's phallic 'pen'. In his declaration of preference for a loving relationship devoid of power games, Gabriel makes direct reference to a poem that operates on the very sexual (and imperial) power games that he disavows. ${ }^{19}$ In the case of Gabriel's ironic rewriting, the 'pena' is a double signifier of an absence: it points to his mutilated penis and the psychic pain provoked by the memory of it, which is revealed to Myra at the end of her birthday. Like Mafalda, Myra's first master, Gabriel is 'Prospero and Caliban at the same time';20 a master with a body violently marked by colonial violence.

Gabriel is framed as a predator at several moments: he is 'Beast' to Myra's 'Beauty' and a Bluebeard who rears the child Myra for her sexual initiation on her

\footnotetext{
${ }^{19}$ Luís de Camões, A Lírica de Luís de Camões: Textos Escolhidos, Editorial Comunicação, 1981, pp. 81-82.

${ }^{20}$ Ana Filipa Prata, 'Transgression, Transdifference and Abjection in Maria Velho da Costa's Myra and Teresa Vilaverde's Transe', p. 210.
} 
sixteenth birthday. The murkiness of Gabriel's and Myra's relationship is underlined in the description of the 'powerphiles' (poderófilos) that populate Myra's underworld: 'Uma criança cede, cede sempre. Pode chorar, mas cede. Não tem outro remédio. E até pode gostar, o que não é menos horrendo' (Children give in, they always give in. Cry they might, but they always give in. They have no other choice. And, just as horrendous, they might even enjoy it, p. 218). Although the novel's structure suggests that Gabriel's love is the best that Myra can hope for - the 'Casa Branca' is her last stop before the brothel and her premature death — a more sinister reading remains open: that Myra declares that she is in 'love' and that she is 'happy' is no guarantee that her bond with Gabriel is not that of a vulnerable teenager in the thrall of someone who loves power. Myra is wary enough of her master/lover that she only reveals her name to Gabriel as he lies dying on the roadside.

\section{Humbert's Bizarre Mask, Myra's Canny Disguises}

Like Myra, Lolita is a girl who 'might even enjoy' her captivity by a powerphile. As Dimitri Nabokov notes, in his comparison of Lolita and her prototype - the girl in The Enchanter - that the latter is: 'perverse only in the madman's eyes; innocently incapable of anything like the Quilty intrigue'. ${ }^{21}$ When Humbert catches up with Dolores, several years after she disappears from a hospital, she tells him that she was not abducted by Clare Quilty: she left willingly.

Lolita's escape from Humbert underlines the slipping control that the abuser has over his victim as Lolita grows up. However, the abuser's control over Lolita's

\footnotetext{
${ }^{21}$ Dimitri Nabokov, 'On a Book Entitled The Enchanter', p. 213.
} 
identities is fragile at best throughout the text on the level of representation. The reader is made aware, from the text's second paragraph, that Lolita and her many, splintered forms are highly artificial creations:

She was Lo, plain Lo, in the morning, standing four feet ten in one sock. She was Lola in slacks. She was Dolly at school. She was Dolores on the dotted line. But in my arms she was always Lolita.

(Lolita, p. 9)

These sentences are particularly revealing about what happens to Lolita's identity in the text: she is hewn by Humbert into a series of sexualised images, behind which may lie the 'real' Lolita, the 'true' version that John Ray encourages us to seek, but which Nabokov, a patent detester of mimesis and 'realism', seems to reject both in his afterword to the novel, ${ }^{22}$ and through the device of Ray. There is no 'real' Lolita to find other than that imagined by her abuser.

Nabokov was highly conscious of the inherent dangers of writing a book like Lolita: Ray's foreword and Nabokov's afterword underline three major concerns. First, that the book will be dismissed, "not based on my treatment of the theme but on the theme itself' (p. 314) — a subject to which I will return later. Secondly, Nabokov is wary of the reader who will disparage Lolita for its lack of realism, a critique that Nabokov rejects by asserting his preference for 'aesthetic bliss', or 'a sense of being somehow, somewhere connected with other states of being where art (curiosity, tenderness, kindness, ecstasy) is the norm' (pp. 314-315). Thirdly, Nabokov is alert

\footnotetext{
${ }^{22}$ In 'On a Book Entitled Lolita', Nabokov evinces his suspicion of the term 'reality', and questions whether the term, in the realm of literature, has any meaning: ' $[\ldots]$ I was faced by the task of inventing America. The obtaining of such local ingredients as would allow me to inject a modicum of average "reality" (one of the few words which mean nothing without quotes) into the brew of individual fancy [...]', Lolita, p. 312. Nabokov parodies 'realistic' writing: 'Some of the reactions [from publishers to the manuscript of Lolita] were very amusing: one reader suggested that his firm might consider publication if I turned my Lolita into a twelve-year old-lad and had him seduced by Humbert, a farmer, in a barn, amidst gaunt and arid surroundings, all this set forth in short, strong "realistic" sentences ("He acts crazy. We all act crazy, I guess. I guess God acts crazy." Etc.)', p. 314.
} 
to that brand of reader who looks for biography in the fiction, who sees Ray and Humbert as manifestations of the author. Nabokov's novel, as well as the metatexts that frame it, are attempts to deny the existence of a (more) 'truthful' reality hiding behind the masks worn by the characters that populate Lolita: Humbert Humbert and the artificial vizard(s) that the girl he abuses is forced to wear.

The image of the mask is introduced by Ray in relation to the strange name of Lolita's narrator, whose 'bizarre cognomen is his own invention; this mask — through which two hypnotic eyes seem to glow — had to remain unlifted in accordance with its wearer's wish' (p. 3). Nabokov tempts the reader to make the leap from fictional narrator to author, whilst also denying that very possibility. He does a similar thing in his afterword, where he adopts the language of Lolita's narrator in a text that mocks readers who have interpreted the novel as a semi-biographical work: 'The first little throb of Lolita went through me late in 1939'; 'I find [Lolita] to be a delightful presence now that it quietly hangs about the house like a summer day which one knows to be bright behind the haze' (p. 311; 316, my emphasis). Nabokov teases his reader, daring them to make the (il-)logical leaps from protagonist, narrator or fictional editor, to author.

Here, one of the crucial differences between Myra and Lolita emerges. Like Nabokov, Velho da Costa is aware of the performative, theatrical aspect of identity. However, in Myra, there is no such play when it comes to the possible existence of a lingering identity behind the various disguises that Myra dons. Along with her guard dog and companion Rambo, Myra's names and slap-dash identities are her only defence against the potential predators she encounters. 
Myra only willingly reveals her given name to one other human being in the novel — to Gabriel Orlando:

- Kiss me, Kate.

- Myra, chamo-me Myra, chamo-me Myra, meu amor.

("Kiss me, Kate."

"Myra. My name is Myra. My name is Myra, my love.")

(Myra, p. 192)

At the zenith of vulnerability and despair, Myra's masks fall as she rejects Kate simultaneously an abbreviated form of Ekaterina, the identity that Myra creates for Gabriel, and Gabriel's Kiss me 'Kate' - a Humbertian artifice. Myra spends the remainder of the novel exposed, as her kidnappers sneeringly address her by the name that she reveals to Gabriel: 'Que ela gosta mesmo é de cães, não é Miss Myra?' (She really does like dogs, don't you Miss Myra? p. 194). Myra and Rimbaud, who is recognised as a successful fighting dog, do not last the night. The coincidental timing of Myra's unmasking and her premature death is not innocent: Myra's suicide/murder ${ }^{23}$ occurs at the point when she exposes her chosen identity. Myra is forced out of hiding with the death of Gabriel. This Myra — one denied the possibility of telling of her own story through her mendacious contos — cannot be reconciled with the novel's dangerous underworld. Exposed to her kidnappers, Myra does not invent a new identity before her suicide on the novel's last page.

Myra's ability to adopt different roles and outwit the predators that threaten her is testament to her talents as a performer who is able to thwart, at least for a time,

\footnotetext{
23 '[Myra] Lembrou-se de Ernst Kleber, o bom alemão, os suicidas são sempre assassinados', ([Myra] Remembered the words of Ernst Kleber, the good German: suicide is always murder) p 220. The notion that suicide is always murder had appeared in Costa's 1983 novel Lucialima.
} 
an overbearing, kyriarchal power structure. ${ }^{24}$ Maria Irene Ramalho Santos has written that, in contrast to the nonverbal Maina Mendes, 'the polyglot Myra refuses to be pinned down by a name. She calls herself [...] different names, in freedom-fighting gestures of hidden sense'. ${ }^{25}$ Unlike 'Lolita', a sexualized identity foisted upon the 'real' girl that Humbert kidnaps and abuses, 'Myra' is a chosen identity, constituted of and protected by the alter egos that are hastily invented by the protagonist. These multiple identities are constitutive of a tessellated, supra-identity 'Myra': a name that gathers meaning as the child grows, even if that meaning is not allowed to burgeon to its full potential. This supra-identity, constituted of myriad, fleeting personae, serves to protect a different Myra: the Russian adolescent who only reveals herself to her dog and to her lover as he gives out his dying breath. This hidden Myra embodies the childhood that is denied her.

In an article on the importance of place names in Lolita, Monica ManolescuOancea argues that in Nabokov's stated project to 'invent' America, the author creates a continental patchwork described over the course of the novel: 'Nabokov's America is best rendered, visually and kaleidoscopically, by the image of the patchwork, "the crazy quilt of forty-eight states" that features in Lolita'. ${ }^{26}$ Nabokov's spatial quilt is constituted of a 'rainbow of "realities", ${ }^{27}$ a combination of real and fictional place names that create a 'motley ${ }^{\prime 28}$ textual space, which is navigated by 'a spatial discourse of seduction', oriented along the 'geometrical shapes of voluptuous digression' ${ }^{29}$

\footnotetext{
24 Elisabeth Schüssler Fiorenza, 'Introduction: Political Construction of Feminist Biblical Interpretation' in But She Said: Feminist Practices of Biblical Interpretation (Boston: Beacon Press, 1992), pp. 1-18.

25 Santos, p. 197.

26 Monica Manolescu-Oancea, 'Inventing and Naming America: Place and Place Names in Vladimir Nabokov's Lolita', European Journal of American Studies, 4 (1) (2009), p. 2.

${ }^{27}$ Manolescu-Oancea, p. 4.

${ }^{28}$ Manolescu-Oancea, p. 5

${ }^{29}$ Manolescu-Oancea, p. 7.
} 
Manolescu-Oancea remarks that Nabokov's invented North America reflects Humbert Humbert's patchwork configuration: 'Genetically and metaphorically, Humbert is a quilt himself'. ${ }^{30}$ She notes that the intrusions of Nabokov's fictional place names 'allow Nabokov to invent and at least appropriate America by (partially) naming it all over again'. ${ }^{31}$ This reflection might be applied equally to Humbert's renaming and subsequent appropriation, on the levels of diegesis and literary representation, of the child that he abducts. To name and rename is the prerogative of the powerful; of people (typically men) like Humbert, the white male abuser. ${ }^{32}$ In 'On a Book Entitled Lolita', Nabokov rejects moral charges against his work. However, it is telling that Nabokov is more interested in creating a multi-faceted America and complex figure out of the predatory Humbert, than he is in creating a rounded character out of Lolita. This is not to say that Nabokov sides with his 'creature', Humbert; he clearly does not: 'there are many things, besides nymphets, in which I disagree with him' (Lolita, p. 315). Nabokov privileges the voice of the presumed interesting male predator, even if he does so to disparage him. Meanwhile, the victim is silenced by Humbert and Ray, who take control of her narrative and her literary representation.

\section{Writing against Moral Policing, Writing at the Heart of a Scandal}

How might this difference in approach to the sensitive topic of paedophilia be explained? The contexts in which Myra and Lolita were produced, and published, are

\footnotetext{
${ }^{30}$ Manolescu-Oancea, p. 5.

${ }^{31}$ Manolescu-Oancea, p. 8.

32 John Ray Jr. on the novel's title: 'Lolita, or the Confession of a White Widowed Male, such were the two titles under which the writer of the present note received the strange pages it perambulates' (Lolita, p. 3).
} 
fundamental to understanding the authors' respective treatments of similar subject matter.

In the book Girls Lean Back: The Law of Obscenity and the Assault on Genius, Edward de Grazia dedicates a chapter to the difficulties that Nabokov encountered in trying to publish Lolita in France, the USA, and the United Kingdom, including the 'lolitigation' levelled against the Olympia Press, the French publishing house infamous for its catalogue of 'd.b.'s (dirty books) run by Maurice Girodias. ${ }^{33}$

In the United States, the legal framework regarding obscenity in literature was unclear at the time that Nabokov first sent manuscripts of Lolita to North American publishers in 1954. In 1948, the Supreme Court had been called upon to rule on a case brought against Edmund Wilson's Memoirs of Hecate County, which had been suppressed on obscenity charges by the Court of Special Sessions of New York. A tied vote 4-4 resulted in the lower court's decision being upheld. Grazia writes that 'the split and silent decision left authors and publishers hopelessly adrift in a sea of conflicting lower court judicial decisions and opinions'. ${ }^{34}$ Changes in the law developed gradually: in the 1957 Roth case the Supreme Court 'held enigmatically that "obscenity" was not constitutionally protected expression, but also that literary and artistic "discussions" of sex having even the slightest social importance ought to

\footnotetext{
${ }^{33}$ For an account of the trials and tribulations of Lolita's publication in France, see Edward de Grazia, Girls Lean Back Everywhere: the Law of Obscenity and the Assault on Genius (London: Constable, 1992), pp. 255-72.

${ }^{34}$ Grazia, p. 250.
} 
be constitutionally protected'. ${ }^{35}$ Grazia states that: 'Not until June 1959 [...] did the Supreme Court make it clear that a book could not be banned for its sexual immorality'. ${ }^{36}$

In the foreword to Lolita, Ray makes reference to the case brought against James Joyce's Ulysses in 1933 on the grounds of obscenity (Lolita, p. 4). After a Shakespeare and Company edition of Ulysses had been seized by customs in New York, the publisher, Random House, went to federal court in an attempt to clear the obscenity charges brought against the Shakespeare and Company edition, and thereby make the novel available for publication in the US. Sitting judge John H. Woolsey's ruling marked 'a new and, for its time, liberal approach to the definition of the obscene', for he 'held that the work as a whole had literary merit but no aphrodisiacal impact on the average person' ${ }^{37}$

Through the device of Ray and in his afterword to the novel, Nabokov demonstrates that he was highly conscious of the dangers of trying to publish a book like Lolita in the USA, fearing the prospect of criminal charges and dismissal from his teaching position at Cornell University. Nevertheless, in the context in which the novel was composed and then published, Lolita stands as a challenge to North American obscenity laws, as the author, in various guises, goads the sort of reader that he disparages in 'On a Book Entitled Lolita' to label his novel and its writer(s) and editor obscene. At the same time that Nabokov mocks the reader who looks for

\footnotetext{
${ }^{35}$ Grazia, note on p. 250. Grazia states that 'Not until June 1959 [...] did the Supreme Court make it clear that a book could not be banned for its sexual immorality'.

${ }^{36}$ Grazia, note on p. 250.

${ }^{37}$ Grazia, p. 30. For an account of the various controversies that Ulysses provoked in the United States, including the 1933 judgement to which John Ray Jr. refers, see Grazia, pp. 7-39.
} 
autobiographical details in fictional works, he dares his readership to identify Nabokov-the-artist with Humbert and Ray.

Whereas Nabokov interrogates the question of decency in literature in a climate of McCarthyism through the first-person narrative of a child abuser, Velho da Costa's novel is a work produced at a time when a decades-old child abuse scandal, involving a state-run institution and powerful men positioned in several circles of the Portuguese elite, was putting enormous pressure on the country's legal system, the State, and the media.

Velho da Costa had previously experienced legal (and political) difficulties with the publication of her collaborative project Novas Cartas Portuguesas in 1972. ${ }^{38}$ In 2008, she published Myra against the backdrop of the Casa Pia scandal - a case of child sexual abuses dating from the mid-1970s involving children and employees at the Casa Pia, a state-run institution for the care of under-privileged children and orphans in Lisbon. The story broke in November $2002,{ }^{39}$ provoking a media circus involving newspapers, television, and radio, with all arms of the Portuguese media bearing the brunt of stern criticism and 'humiliation'. ${ }^{40}$ After a drawn-out legal process, six men were formally charged on 3 September 2010 - a group that included a doctor, a lawyer, a TV presenter, a retired ambassador, and a former Casa Pia

\footnotetext{
${ }^{38}$ For a study of the book's reception in Portugal, see Ana Luísa Amaral, Ana Paula Ferreira, and Marinela Freitas (eds.), New Portuguese Letters to the World: International Reception (Oxford: Peter Lang, 2015), pp. 11-48.

${ }^{39}$ An article published twenty-one years earlier by Portuguese tabloid Tal e Qual in July 1981 called 'Prostituição masculina tinha Mercado na Casa Pia' (Male Prostitution had a Market in the Casa Pia) had been ignored by the Portuguese press and the public. Madalena Oliveira, 'A Casa Pia e a imprensa: jornalistas em acto de contrição: a impiedade das críticas ou auto-regulação?' in Manuel Pinto and Helena Sousa (orgs) Casos em que o Jornalista Foi Notícia (Porto: Campo das Letras, 2007), p. 126.

${ }^{40}$ Oliveira, p. 136.
} 
governor. It is no accident that the kidnapper who wants exclusive access to Myra is a 'doutor' — in Portugal, a term, normally used as a marker of social status, designating a man holding a university degree.

In Myra, the author's focus is not on the scandal that paedophilia provokes. Myra is the story of an exceptional girl who is denied her childhood in a world where no one, not even the victim, can be innocent. Myra is complicit in this guilty world: in chapter seven she attempts to kill Mafalda, a course of action that places the reader in a moral dilemma: 'Yes, it is self-defence in the interest of survival, but the question remains: Where is the line to be drawn? ${ }^{41}$ One of the most vulnerable members of this dangerous society, Myra is left desperate: 'Myra is a loser in all senses of the word: a foreigner (a Russian girl in Portuguese lands), a woman, a child' ${ }^{42}$ Myra is not Beauty (to Gabriel's Beast), Kate or the rest by choice: these identities are necessary to deflecting the predators that threaten to discover her inner identity. In Mafalda's house, Myra remarks: 'A minha vida não é igual às outras [...]. Fui proibida de existir. Fui roubada de poder ser' (My life is not like others' [...]. I was prevented from existing. I was robbed of being. Myra, p. 55). Unlike Lolita, whose death is a footnote to Nabokov's story, Myra's fate takes centre-stage. With Myra, a testament to the worth and importance of untold narratives like that of her protagonist, Velho da Costa reminds her readers that human stories are too often forgotten amidst the scandal.

\footnotetext{
${ }^{41}$ Santos, p. 194.

42 Translated from the Portuguese. Marinho, p. 95.
} 
In Lolita, the control of names and the process of naming are key to the power that the novel's various abusers have over the young girls (Lolita, Mona Dahl) that feature in the novel. Even where the false identity 'Dolores Haze' should protect its bearer, this semi-constructed identity is in fact a deliberately fragile defence that only half-conceals the abused girl who lies behind the vizard wrought by the fictional editor. In Velho da Costa's novel, the contingent identities that Myra invents at moments of great peril are fundamental to her survival strategy in the dangerous underworld that she traverses. The multiplication of names and their attendant identities results in a polyhedral identity. The difference in narrative perspective between Myra and Lolita results in Velho da Costa's protagonist being a nuanced imperfect — protagonist, whilst Nabokov's and Humbert's Lolita is relegated to a problematic silence. 